\title{
Determination of Body Image, Self-Esteem and Depression States among Patients with Gynecological Cancer
}

\author{
(D) Nurcan DÜZGÜN,' ${ }^{1}$ (D) Evrim BAYRAKTAR² \\ ${ }^{1}$ Rectorship, Gazi University, Ankara-Turkey \\ ${ }^{2}$ Department of Gynecology and Obstetric Nursing, Erciyes University, Kayseri-Turkey
}

\begin{abstract}
OBJECTIVE
This descriptive study was conducted to investigate the states of body image, self-esteem and depression among patients with gynecological cancer.

\section{METHODS}

The sample of the study consisted of 76 Turkish patients who had gynecological cancer. The Patient Information Form, Body Image Scale (BIS), Rosenberg Self-Esteem Scale (RSES) and Beck Depression Inventory (BDI) were used to collect data in this study. The independent-samples t-test, one-way ANOVA test, Tukey and tamhane's $\mathrm{t} 2$ multiple comparison tests, and Pearson correlation analysis were used for the analyses of data in this study.

\section{RESULTS}

In the study, $30.3 \%$ of the patients were between $60-69$ years old; $64.5 \%$ were married; $42.1 \%$ were primary school graduates, and $84.2 \%$ were housewives. $94.7 \%$ of the patients had negative body images and experienced depressive symptoms, and $77.6 \%$ of them were found to have low levels of self-esteem. It was determined that there was a significant negative correlation between BIS and BDI ( $r=-0.822$; $\mathrm{p}<0.001)$; a significant and positive correlation between BIS and RSES $(r=0.747 ; \mathrm{p}<0.001)$, and a significant and negative correlation between RSES and BDI $(\mathrm{r}=-0.793 ; \mathrm{p}<0.001)$.
\end{abstract}

\section{CONCLUSION}

The findings obtained in this study showed that patients with gynecological cancer experienced severe depressive symptoms, and their body image and self-esteem states were affected negatively. Patients with gynecological cancer need psychosocial support with a holistic approach in addition to medical treatment.

Keywords: Body image; depression; gynecological cancers; self-esteem.

Copyright $\odot$ 2020, Turkish Society for Radiation Oncology

\section{Introduction}

Among the cancer types observed in women, gynecological cancers constitute an important health problem due to their morbidity and mortality rates.[1] Gynecological cancers are the most common cancer types seen among women following breast cancer; however, the mortality rates of gynecological cancers are higher than breast cancer.[2] The incidence of gynecological cancers among all cancer types in women is approximately $5.0 \%$ for uterine corpus cancer, $3.7 \%$ for ovarian cancer, and $2.5 \%$ for cervical cancer.[3] The most common 
psychopathology observed in cancer patients is depression, [4] and patients having cancer experience higher levels of depression than a healthy population.[5]

In a study that evaluated the relationship between gynecological cancers and depression, major depression was detected in $24.1 \%$ of the patients.[6] In another study, depressive symptoms were detected in $55.0 \%$ of the patients.[7] Parker et al. reported that patients, who survived after gynecological cancer, had higher anxiety and depression levels and lower wellbeing than patients who survived after other types of cancer.[8]

Depression experienced commonly by gynecological cancer patients depends on many factors. Some of these factors are uncertainty about the treatment process, fear for the metastasis of disease to other organs and fear of death, changes in sexuality, difficulties in daily life activities, low emotional support and deterioration in self-esteem and body image.[9]

In many societies and in our country, reproductive organs are accepted as indicators of fertility, femininity, sexuality, and motherhood of women; and play a decisive role in shaping women's body image, self-esteem and sexual identity. Many women consider their reproductive organs and their functions as equal to being a woman.[10] Thus, any disease or damage to reproductive organs is a severe threat to them. Women begin to feel that their femininity and sexuality are in danger and perceive themselves as being useless, ugly, imperfect, and incomplete.[11]

This change in a woman's perception of her own body causes a negative body image and low self-esteem.[12,13] In previous studies, it was reported that changes in body integrity due to gynecological cancer and the treatments applied to women affected their body image and self-esteem in a negative way.[14,15] In addition, many women have negative thoughts following a radical surgical treatment like radical hysterectomy and radical vulvectomy as they will lose their charm and their husbands will not like them. Thus, their sexual lives will be affected.[12] Several side effects, such as alopecia, change in skin color and weight loss, after the treatments used may be effective in decreasing self-esteem by causing negative changes in the body image scores of women. These changes in body image and self-esteem increase the tendency for depression in cancer patients. [16]

Today, modern nursing practices aim to realize biopsychosocial approaches and to provide holistic care services to integrate physical and psychosocial care. The holistic approach requires addressing an in- dividual's response towards the disease together with the disease itself. Identifying and treating psychosocial problems of gynecological cancer patients are important in providing holistic patient care and in increasing the quality of treatment-care.

Although there are some studies in the literature on the psychosocial effects of cancer in Turkey, to our knowledge, no studies were found on the body image, self-esteem and depression levels of women with gynecological cancer. It was decided to conduct this current study to provide data for future research and to provide holistic care for women with gynecological cancer.

This study was carried out to investigate the states of body image, self-esteem and depression in patients with gynecological cancer.

\section{Materials and Methods}

This descriptive study was conducted with patients who were receiving chemotherapy due to gynecological cancer in the oncology day treatment center affiliated with a university hospital in Kayseri in Turkey. A total of 141 patients admitted to this unit in 2016. The sample size of this study was calculated using a power of $90 \%$ and an error rate of 5\%, and depression was estimated as the most important variable. The frequency of depression was accepted as $25 \%$ based on the values in the references given for the definition of the problem. In this case, the statistical values were planned as follows: $\alpha=0.05, \beta=0.19$, prevalence $=0.25, n=141$, and power $=0.80$.

The sample of this study consisted of 76 gynecological cancer patients (noverca $=40$, nserviksca $=12$, nendometriumca $=24$ ), who were treated at the oncology day treatment center between January and July 2017.

\section{Data Collection Tools}

The data of this study were collected using the Patient Information Form, Body Image Scale (BIS), Rosenberg Self-Esteem Scale (RSES), and Beck Depression Inventory (BDI).

\section{Patient Information Form}

Patient Information Form consisted of the following three parts:

In the first part, there were questions on age, marital status, educational status, occupation, employment status, income level, social insurance status, family type, people with whom the patient lives, geographical region, height/weight/BMI, age at first delivery, the number of deliveries, state of having a gynecological 
cancer patient within the family, menopausal status, the menopausal age, smoking and alcohol use of the gynecological cancer patients.

In the second part, characteristics like the primary diagnosis and diagnosis date of the patient, time to start treatment and chemotherapy, number of chemotherapy cures, state of receiving radiotherapy, state of having any other disease and state of undergoing any surgical operations and features of gynecological cancer and treatment were evaluated.

In the Third Part, there were questions to evaluate the psychological state of the patient such as having any psychological diseases in the past and if yes, their names and treatments received, having any psychological disease at present, the difficulties experienced during the illness, and the need for psychological support.

\section{Body Image Scale (BIS)}

BIS was developed by Secord and Jourard 1953,[17] and it was adapted to the Turkish language by Hovardaoglu following its reliability and validity study in 1989.[18] The scale contains 40 items, and each item is associated with an organ or part of the body (i.e., arm, leg, face) or a function (i.e., level of sexual activity). Each item is given a score ranging from 1 to 5 , and there are response options like "I like it very much" (5 points), "I like it much (4 points), "I am indecisive" (3 points), "I do not like it" ( 2 points), and "I do not like it at all" (1 point). The scale does not have a cut-off value. A total score of 40 to 200 may be obtained from the scale, and high scores show high satisfaction levels. This scale is recommended to be used, especially in studies related to depression. The Cronbach's a value was found to be 0.923 in this study.

\section{Rosenberg Self-Esteem Scale (RSES)}

RSES was developed by Morris Rosenberg in 1965.[19] The validity and reliability study of the scale was conducted by Cuhadaroglu.[20] RSES is a self-report scale, and consists of 63 multiple-choice questions. The scale consists of twelve subscales. Rosenberg stated that the subscales could be used separately in studies. In line with the aim of the present study, the first 10 items were used to measure self-esteem. In this 10 -item scale, including five positive and five negative statements, the scoring is done according to GuttmanScaling Technique. It is a 4-point Likert type scale with options including "Strongly Agree", "Agree", "Disagree", and "Strongly Disagree"; and five of the questions are coded reversely. Based on the self-assessment system of the scale, items 1, 2, 4, 6 and 7 question positive self-assess- ment; and has a scoring ranging from 3 to 0 . Items 3,5 , 8,9 and 10 question negative self-assessment; and scoring is done as ranging from 0 to 3 . The total score varies between 0 and 30 . A score between 15 and 25 shows that self-esteem is at an adequate level, and a score below 15 indicates a low self-esteem. In this study, the Cronbach's a value of the scale was found to be 0.793 .

\section{Beck Depression Inventory (BDI)}

The original form of the scale was prepared by Beck et al. The BDI has two versions, including one version from 1961 [21] and the other version from 1978.[22] Both versions were translated into Turkish, and its validity and reliability studies were conducted. Its 1978 version, adapted by Hisli,[23] was used in this study. In a previous study that was conducted with university students, Cronbach's a coefficient of BDI was reported as 0.80 . There are four options for each of the 21 symptom categories in the BDI form. The patient is asked to choose the best sentence expressing how she/he felt in the last week, including the admission day. Each item is scored between 0 and 3 . The highest score that may be received is 63. A high total score indicates that the level or the severity of depression is high. The scale may be applied to people over the age of fifteen. While the Turkish version of BDI was developed, the cut-off points were examined; and it was found that the scores of 17 and above were able to distinguish the depression that might require treatment with an accuracy of $90 \%$. In this study, the Cronbach's a value of the scale was found to be 0.893 .

\section{Data Analysis}

The data were analyzed using SPSS 21.0 (Statistical Package for Social Sciences) Package Program. The normality of the data was tested by Shapiro-Wilk test. The independent samples t-test and one-way ANOVA test were used for the assessment of data. After the variance analysis, the Tukey and tamhane's $\mathrm{t} 2$ multiple comparison tests were used to investigate the source of difference among the groups. The Pearson correlation analysis was used to determine the correlations between BDI, BIS and RSES scores. A $\mathrm{p}<0.05$ value was considered to be statistically significant.

\section{Results}

The ages of the patients, who participated in the present study, were between 34 and 79 years, and mean age was $59.06 \pm 11.21$ years old. $64.5 \%$ of the patients were married; $30.3 \%$ were between $60-69$ years old; $42.1 \%$ were 
primary school graduates, and $84.2 \%$ were housewives (Table 1). According to the fertility and menopause states, it was determined that $61.9 \%$ of the patients gave their first births between the ages of 19-25 years old; and $50.0 \%$ of them enteredmenopausebetween the ages of $40-49$ years old. $35.5 \%$ entered menopause due to surgical treatment, and $39.5 \%$ had $1-3$ children. In addition, $52.6 \%$ of them had ovarian cancer, and diagnosis time was less than one year in $77.6 \%$. 97.4\% of the patients did not have a mental illness. However, $31.9 \%$ of them stated that they had difficulties in psychological terms, and $67.1 \%$ expressed their need for psychological support.

The mean BIS score of the patients was $94.02 \pm 21.90$; the mean RSES score was $11.42 \pm 4.10$, and the mean BDI score was $30.86 \pm 10.30$ (Table 2). In this study, $94.7 \%$ of the patients reported a negative body image, $77.6 \%$ had low self-esteem, and $94.7 \%$ of them experienced depressive symptoms (Table 3 ). The findings showed that there was a negative and very significant correlation between body image and depression status, a positive and significant correlation between body im-

Table 1 Sociodemographic characteristics of the patients $(n=76)$

\begin{tabular}{lcc} 
Characteristics & $\mathbf{n}$ & $\%$ \\
\hline Age group (years) & & \\
$30-39$ & 3 & 3.9 \\
$40-49$ & 13 & 17.1 \\
$50-59$ & 22 & 28.9 \\
$60-69$ & 23 & 30.3 \\
$70-79$ & 15 & 19.7 \\
Age (Mean \pm SD) & $59.06 \pm 11.21$ & \\
& (Min:34.0-Max:79.0) & \\
Marital status & & \\
Married & 49 & 64.5 \\
Single & 25 & 32.9 \\
$\quad$ Divorced & 2 & 2.6 \\
Educational status & & \\
Literate & 31 & 40.8 \\
Primary school & 32 & 42.1 \\
Secondary school & 4 & 5.3 \\
High school & 5 & 6.6 \\
$\quad$ University & 4 & 5.3 \\
Occupation & & \\
Housewife & 64 & 84.2 \\
Retired & 3 & 3.9 \\
Teacher & 2 & 2.6 \\
$\quad$ Employee & 2 & 2.6 \\
Other (Cook, tailor, officer, & 5 & 6.6 \\
accountant, tourism business) & & \\
\hline$\quad$ & & \\
\hline & &
\end{tabular}

Table 2 Mean BIS, RSES and BDI scores of the patients $(n=76)$

\begin{tabular}{lcc} 
Scales & Mean \pm SD & Min-Max \\
\hline BIS & $94.02 \pm 21.90$ & $(55.0-146.0)$ \\
RSES & $11.42 \pm 4.10$ & $(3.0-21.0)$ \\
BDI & $30.86 \pm 10.30$ & $(12.0-56.0)$ \\
\hline
\end{tabular}

Table 3 BIS, BDI and RSES scores of the patients $(n=76)$

\begin{tabular}{lcc} 
BIS, BDI and RSES scores & $\mathbf{n}$ & $\%$ \\
\hline BIS score & & \\
134 and below (negative body image) & 72 & 94.7 \\
$\begin{array}{l}135 \text { and above (positive body image) } \\
\text { RSES score }\end{array}$ & 4 & 5.3 \\
14 and below (low self-esteem) & 59 & 77.6 \\
15 and above (high self-esteem) & 17 & 22.4 \\
BDI score & & \\
16 and below (no depressive symptoms) & 4 & 5.3 \\
17 and above (depressive symptoms) & 72 & 94.7 \\
\hline
\end{tabular}

age and depression status, and a negative and significant correlation between self-esteem and depression status (Table 4).

When body image, self-esteem and depression states of the patients were examined based on their sociodemographic and disease characteristics, it was determined that patients within 30-49-year-old group had lower self-esteem and higher depression states $(p<0.05)$. No statistically significant difference was detected between mean BISscore and age $(p>0.05)$. Moreover, no statistically significant differences were detected between the education, occupation, social insurance, type of cancer and time of diagnosis and their mean BIS, RSES and BDI scores ( $p>0.05)$.

When the characteristics of the patients in this study were evaluated concerning fertility and menopausal status, the findings showed that there were no statis-

\begin{tabular}{|c|c|c|c|c|c|c|}
\hline Table 4 & $\begin{array}{l}\text { The c } \\
\text { amol }\end{array}$ & $\begin{array}{l}\text { orrelatio } \\
\text { ng the pa }\end{array}$ & $\begin{array}{l}\text { betwe } \\
\text { ients }\end{array}$ & n BIS, RSE & S and B & \\
\hline \multirow[t]{2}{*}{ Scales } & \multicolumn{2}{|c|}{ BIS } & \multicolumn{2}{|c|}{ RSES } & \multicolumn{2}{|c|}{ BDI } \\
\hline & $\mathbf{r}$ & $\mathbf{p}$ & $\mathbf{r}$ & $\mathbf{p}$ & $\mathbf{r}$ & $\mathbf{p}$ \\
\hline BDI & $-0.822 *$ & $<0.001$ & & & & \\
\hline BIS & & & 0.747 & $<0.001$ & & \\
\hline RSES & & & & & -0.793 & $<0.001$ \\
\hline
\end{tabular}


tically significant differences between the variables of age at first delivery and menopausal age and their states of body image, self-esteem and depression ( $p>0.05$ ). The self-esteem of the patients, who did not experience any delivery, was found to be lower than the patients who had one or more child births $(\mathrm{p}<0.05)$. In addition, patients who entered menopause due to a surgical treatment had lower BIS and RSES scores and higher BDE scores than patients who entered physiological menopause $(\mathrm{p}<0.05)$.

In this study, women who had a current psychological illness were determined to have lower self-esteem and a higher level of depression compared to patients who did not have any psychological diseases $(p<0.05)$. No statistically significant difference was detected between body image and the state of having a psychological illness at the moment when this study was conducted $(\mathrm{p}>0.05)$. When the body image, selfesteem, and depression states were examined based on the need for psychological support, it was found that the patients, who needed psychological support, had a more negative body image, had lower self-esteem but experienced more depressive symptoms compared to patients who did not $(\mathrm{p}<0.05)$.

\section{Discussion}

Depression is the most common psychiatric disorder experienced by gynecological cancer patients. [24] The relationship between depression and gynecological cancers was reported frequently in the literature.[6,25] Suzuki et al. reported depressive symptoms at a rate of $55 \%$ among the patients having gynecological cancers.[7] In the present study, nearly all of the women (94.7\%) experienced symptoms of depression together with gynecological cancer. In this study, depression states of women were determined to be higher than in other studies. The reason may be that all women included in this study underwent a surgical treatment and they were actively receiving chemotherapy during the dates of this study.

There may be several factors in gynecological cancers that may cause depression in women. It was reported in the literature that using chemotherapeutic agents was one of these risk factors. [4] Another risk factor is the surgical treatment applied.[9] The loss of estrogen following surgical treatment poses a biochemical basis for the generation of depression.[26] Onethird of women who were included in the present study (35.5\%) entered menopause due to surgical treatment, and they were determined to have significantly higher
BDI scores than the women who entered menopause naturally $(\mathrm{p}<0.05)$.

Consistent with the literature, in this study, some of the women (31.9\%) experienced psychological problems during the treatment of disease and that more than half of them (67.1\%) was in need of psychological support. In addition, mean BDI scores of the women, who needed psychological support, were significantly higher than the women who did not $(\mathrm{p}<0.05)$.

In the studies related with the epidemiology of depression, it was reported that the possibility of experiencing depression in young and middle-age groups was higher than in the other age groups, and depression was at its peak in women between 35-45 years old. $[27,28]$ In parallel to the literature, the mean BDI score of the middle age (30-49 years) group where fertility was ongoing was found to be higher at a statistically significant level $(\mathrm{p}<0.05)$.

One of the factors which may affect the depression states of gynecological cancer patients is the number of children. In the study conducted by Gol and Asilar in 2017 with gynecological cancer patients who received chemotherapy, higher depressive symptoms were detected among women having no children compared to those with 1-3 children.[29] However, no statistically significant differences were detected between the number of deliveries and BDI scores in this study ( $p>0.05)$. This situation may be related to small sample sizes.

In the literature, a negative correlation was reported between education and depression. In the study conducted by Kayahan et al., their findings showed that depression was highest among the patients with a low education level, and its prevalence decreased as education level increased.[30] However, no statistically significant differences were detected between the BDI scores and education level in this study ( $p>0.05)$. Consistent with the Ustundag et al.s findings, education level and depressive findings were not found to be correlated in this study.[31]

Another factor that may affect the rate of depression in cancer patients, is the duration of the disease. In the study, which was conducted by Atesciet al., it was stated that depression scores increased as the duration of disease increased.[32] However, Dehkordi et al. concluded in their study that there was no relationship between depression and disease duration.[33] In this study, no statistically significant differences were detected between the times of diagnosis and treatment and mean BDI scores ( $\mathrm{p}>0.05)$.

Problems regarding body image and self-esteem are also important among the ones that are experienced by 
gynecological cancer patients. $[12,13]$ In previous studies, it was reported that loss of reproductive organs and sexual functions in women caused a disruption in body image; and self-esteem scores reduced due to this damage on body integrity. $[10,15,31,34,35]$ Almost all of the patients who were included in the present study (94.7\%) had negative body image, and the majority (77.6\%) had low self-esteem scores. Besides, there was a strong and significant correlation between body image and self-esteem in line with the literature $(\mathrm{r}=0.747, \mathrm{p}<0.001)$.

When the relationship between depression, body image and self-esteem was considered in this study, the findings showed that there was a very strong and significant correlation between body image and depression scores $(\mathrm{r}=-0.822 ; \mathrm{p}<0.001)$; and there was a negative, strong and significant correlation between self-esteem and depression $(\mathrm{r}=-0.793 ; \mathrm{p}<0.001)$. In other words, depressive symptoms were detected at high levels in women with a negative body image and low self-esteem score. Similarly, Ustundaget al. reported that there was a significant and negative correlation between body image, self-esteem, and depression scores in patients with gynecological cancer, and high depression scores affected BIS and RSES scores at a significant level.[31] However, in this study, the BIS and RSES scores of women who needed psychological support were determined to be significantly lower than those who did not $(\mathrm{p}<0.05)$. The BIS and RSES scores of the women with gynecological cancer who needed psychological support were negatively affected and they experienced more severe depressive symptoms in this study was another evidence proving that women were affected psychologically. In addition, RSES scores were significantly lower in women who were diagnosed with a psychological illness (depression) compared to those without a diagnosis of a psychological disease $(\mathrm{p}<0.05)$; and the BIS scores were found to be lower in patients who were diagnosed with a psychological illness although not at a statistical level ( $p>0.05)$. This situation shows that there is a significant relationship between depression and body image and self-esteem.

Surgical treatment is one of the most important factors leading to an impaired body image in individuals who are diagnosed with gynecological cancer. [36] In this study, women who were menopausal due to surgery had negative body image and lower self-esteem scores were compared to the women who entered physiological menopause, and the difference was found to be significant at a statistical level $(\mathrm{p}<0.05)$.

In this study, it was found that there were no statistically significant differences between the mean BIS and RSES scores based on sociodemographic characteristics, such as marital status, family structure and living alone ( $p>0.05)$. Similar to our study, Bisselling et al. reported in their study with 62 patients that the characteristics of family structure did not affect BIS scores.[37]

According to many women, having a healthy uterus means that they are fertile and feminine. Fertility and motherhood have an important place in the role given to women by society. Gynecological cancers appear as a threat to the femininity and fertility of women.[38] In this study, statistically significant differences were detected between mean RSES scores of women with four and more children and women who did not give birth at all; and the RSES scores of those, who did not give birth at all, were found to be lower than women who had four and more children at a significant level $(p<0.05)$. No statistically significant differences were detected between the mean BIS scores and the number of births ( $p>0.05)$.

There are studies in the literature showing that sociodemographic characteristics, such as age and educational status affect body image and self-esteem.[39,40] In the studies carried out with gynecological cancer patients, it was reported that young patients had more negative body image and lower self-esteem than the patients at advanced ages. [14,40] In this study, it was determined that women between the ages of 30-49 years had a more negative body image than the women who were aged 50 years and older; but the difference was not statistically significant ( $p>0.05)$. However, they showed significantly lower self-esteem compared to women aged 50 years and older $(\mathrm{p}<0.05)$. No statistically significant differences were detected between the educational states and their BIS and RSES scores ( $p>0.05$ ). Similarly, in the study conducted by Ustundaget al., education level was not found to be significantly correlated with body image and self-esteem.[31]

When the distribution of BIS and RSES scores was examined based on the characteristics of the disease, it was determined that there were no statistically significant differences between BIS and RSES scores concerning the type of disease and time of diagnosis ( $p>0.05)$. In the study performed by Bisselling et al., it was determined that the clinical factors excep the time of diagnosis did not affect body image.[37]

\section{Study Limitations}

The gynecological cancer patients were from only one university hospital. These results cannot be generalised to a large population. 


\section{Conclusion}

As a result of the present study, it was determined that patients who had gynecological cancer experienced severe depressive symptoms; and their body image and self-esteem were affected negatively. There was a positive and significant correlation between body image and self-esteem. Moreover, body image and self-esteem were found to be negatively correlated with depression level. It must be kept in mind that patients, who have gynecological cancers, need psychosocial support in addition to medical treatment, and a comprehensive approach should be considered. Also, nursing interventions should be planned and implemented in this field. In the light of these findings, it may be recommended to conduct similar studies with larger patient groups and conduct experimental studies examining the effectiveness of interventions on individuals who have disrupted body image, low self-esteem and high depression.

Peer-review: Externally peer-reviewed.

Conflict of Interest: No conflict of interest was declared by the authors.

Ethics Committee Approval: This study was approved by the Research Ethics Committee (Approval number: 347 10/06/2016).

Financial Support: The authors declared that this study received no fund.

Authorship contributions: Concept - N.D., E.B.; Design - N.D., E.B.; Supervision - N.D., E.B.; Funding - N.D.; Materials - N.D.; Data collection and/or processing - N.D.; Data analysis and/or interpretation - N.D.; Literature search N.D., E.B.; Writing - N.D., E.B.; Critical review - N.D., E.B.

\section{References}

1. Ergör G.Türkiye'de Bulaşıcı Olmayan Hastalıklar. In: Ünal B, editor. Kanser Mortalitesi. İzmir: HASUDER Türkiye Halk Sağllk Raporu; 2012. p. 286-7.

2. Abraham J, Allerga CJ, Gulley J. Klinik Onkoloji El Kitabı. In: Mayadağlı A, Parlak C, editors. İstanbul: Nobel Tip Kitabevi; 2009. p. 35.

3. TC. Sağlık Bakanlığı Sağlık İstatistiği Yıllığı. Available at: https://www.saglik.gov.tr/TR,30485/saglik-istatistikleri-yilligi-2016-yayinlanmistir.html. Accessed Jun $15,2020$.

4. Jemal A, Siegel R, Xu J, Ward E. Cancerstatistics, 2010. CA Cancer J Clin 2010;60(5):277-300.

5. Arslan S, Çelebioğlu A, Tezel A. Kemoterapi alan kanserli hastalarda depresyon ve yaşam doyumu- nun belirlenmesi. Türkiye Klinikleri J Med Sci 2008;28(5):628-34.

6. Ell K, Sanchez K, Vourlekis B, Lee PJ, Johnson MD, Lagomasino I. Depression, correlates of depression, andreceipt of depression care among low-income women with breast or gynecologic cancer. Journal of Clinical Oncology 2005;23:3052-60.

7. Suzuki N, Ninomiya M, Maruta S, Hosonuma S, Nishigaya Y, Kobayashi Y. Psychological characteristics of Japanese gynecologic cancer patients after learning the diagnosis according to the hospital anxiety and depression scale. J Obstet Gynaecol Res 2011;37:800-8.

8. Parker PA, Baile WF, De Moor C,Cohen L.Psychosocial and demographic predictors of quality of life in a largesample of cancerpatients. Psycho-Oncology2003;12(2):183-93.

9. Terzioğlu F, Alan H. Jinekolojik kanser tedavisi sırasında yaşanan psikolojik sorunların kadının cinsel yaşamına etkisi. Anadolu Hemşirelik ve Sağlık Bilimleri Dergisi 2015;18:2.

10. Reis N, Coşkun A, Beji NK. Jinekolojik kanserli hastalarda yaşam kalitesi. Anadolu Hemşirelik ve Sağlık Bilimleri Dergisi 2006;9(2):25-35.

11. Anderson B, Lutgendorf S. Quality of life andhomecare as an outcomemeasure in gynecolojical malignancies. Current opinion in Obstetrics and Gynecology 2000;12(1): 21-6.

12. Wilmoth MC, Spinelli A. Sexual implications of gynecologic cancer treatments. JOGNN 2000;29(4):413-21.

13. Reis N. Jinekolojik kanser tedavilerinin kadın cinsel sağlığına etkisi. Cumhuriyet Üniv Hemşirelik Yüksekokulu Dergisi 2003;7(2):35-40.

14. Juraskova I, Butow P, Robertson R, Sharpe L, McLeod C, Hacker N. Post-treatment sexual adjustment following cervical and endometrial cancer: a qualitative insight. Psychooncology 2003;12(3):267-79.

15. Knapstein SH, Fusshoeller C, Franz C, Trautmann K, Schmidt M, Pilch H, et al. The impact of treatment for genital cancer on quality of life and body image-results of a prospective longitudinal 10-year study. Gynecologic Oncology 2004;94(1):398-403.

16. Fobair P, Spiegel D. Concerns about sexuality breast cancer. The Cancer Journal 2009;15(1):19-26.

17. Secord PF, Jourard SM. The appraisal of bodycathexis: Body-cathexis and the self. J Consult Psychol 1953; 17:343-7.

18. Hovardaoğlu S, Özdemir YD. Vücut Algısı Ölçeği’nin güvenirlik ve geçerlik çalışması/Şizofrenik ve major depresif hastaların beden imgelerinden doyum düzeyleri [Dissertation]. Ankara: Gazi Üniversitesi Sosyal Bilimler Enstitüsü, 1990.

19. Rosenberg M. Society and the Adolescent Self-Image. Princeton. New Jersey: Princeton University Press; 1965. 
20. Çuhadaroğlu F. Adolesanlarda benlik saygısı. [Dissertation]. Ankara: Hacettepe Üniversitesi Sosyal Bilimler Enstitüsü, 1986.

21. BECK AT, WARD CH, MENDELSON M, MOCK J, ERBAUGH J. An inventory for measuring depression. Arch Gen Psychiatry 1961;4:561-71.

22. Beck AT, Rush AJ, Shaw BF. Cognitive therapy of depression. New York: Guilford; 1979.

23. Hisli N. Beck Depresyon Envanterinin üniversite öğrencileri için geçerliliği ve güvenirliliği. Psikoloji Dergisi 1989;7:3-13.

24. Petersen RW, Graham G, Quinlivan JA. Psychologic changes after gynecologic cancer. J. Obstet. Gynaecol Res 2005;31:152-7.

25. Steele R, Margaret I. Supportive care needs of women with gynecologic cancer. Cancer Nursing 2008:31(4);288-91.

26. Durmuşoğlu F, Erenus M. Nörovejetatif Semptomlar. In: Ertüngealp E, Seyisoğlu H, editors. Menopoz ve Osteoporoz. 1st ed. İstanbul: Form Reklam Hizmetleri; 2000. p. 23-6.

27. Yalvaç HD. Depresyonun epidemiyolojisi. Türkiye Klinikleri J Psychiatry-Special Topics 2012;5(2):7-13.

28. Sadock BJ, Sadock VA, Ruiz P. Kaplan\&Sadock Psikiyatri. In: Bozkurt A, editor. Davranış Bilimleri/Klinik Psikiyatri. 11th ed. İstanbul: Güneş Tip Kitapevleri; 2016. p. 349.

29. Demir Göl N, Hacıhasanoğlu Aşılar R. Kemoterapi alan kanserli hastalarda depresyon ve yaşam kalitesinin belirlenmesi. Gümüşhane Üniversitesi Sağlık Bilimleri Dergisi 2017;6(1):29-39.

30. Kayahan B, Altıntoprak E, Karabilgin S, Öztürk Ö. On beş-kırk dokuz yaşları arasındaki kadınlarda depresyon prevelansı ve depresyon şiddeti ile risk faktörleri arasındaki ilişki. Anatolian Journal of Psychiatry 2003;4:208-19.

31. Üstündağ MF, Özcan H, Yazla E, Kıvrak Y, Aydın EF, Yllmaz M. Jinekolojik kanserli hastalarda anksiyete ve depresyon semptomları, benlik saygısı ve beden algısı: Kesitsel bir çalışma. Kafkas J MedSci 2017;7(3):214-9.

32. Ateşçi FÇ, Oğuzhanoğlu NK, Baltalarlı B, Baltalarli B, Karadağ F, Özdel O, Karagöz N. Kanser hastalarında psikiyatrik bozukluklar ve ilişkili etmenler. Türk Psikiyatri Dergisi 2003;14(2):145-52.

33. Dehkordi A, Heydarnejad MS, Fatehi D. Quality of life in cancer patients under going chemotherapy. Oman Medical Journal 2009;24(3):204-7.

34. Pinar G, Okdem S, Dogan N, Buyukgonenc L, Ayhan A. Theeffects of hysterectomy on body image, self-esteem, and marital adjustment in Turkish women with gynecologic cancer. Clin J Oncol Nurs 2012;16(3):99-104.

35. Ferguson SE, Urowitz S, Massey C, Wegener M, Quartey NK, Wiljer D, et al. Confirmatory factor analysis of the Sexual Adjustmentand Body Image Scale in women with gynecologic cancer. Cancer 2012;118(12):3095-104.

36. Pınar G. Kanser tedavisi alan hastalarda cinsel disfonksiyon ve danışmanlığına ilişkin hemşirelik yaklaşımları. Gülhane Tip Dergisi 2010;52(4):241-45.

37. Bisseling KC, Kondalsamy-Chennakesavan S, Bekkers RL, Janda M, Obermair A. Depression, anxiety and body image after treatment for invasivestage on epithelial ovarian cancer. Aust N Z J Obstet Gynaecol 2009;49(6):660-6.

38. Frumovitz M, Sun CC, Schower LR, Munsell MF, Jhingran A, Wharton JT, et al. Quality of life and sexual functioning in cervical cancer survivors. Journal of Clinical Oncology 2005;23(30):7428-36.

39. Tahmasebi M, Yarandi F, Efrekhar Z, Montazeri A, Namazi H. Quality of life in gynecological cancer patients. AsianPac J CancerPrev 2007;8(4):591-602.

40. Bifulco G, De Rosa N, Tornesello ML, Piccoli R, Bertrando A, Lavitola G, et al. Quality of life, life style behavior and employment experience: A comparison between young and midlife survivors gynecology early stage cancers. Gynecologic Oncology 2012;124(3):444-51. 